\title{
Distribution, Density, and Biomass of Introduced Small Mammals in the Southern Mariana Islands ${ }^{1}$
}

\author{
Andrew S. Wiewel, ${ }^{2}$ Amy A. Yackel Adams, ${ }^{2,3}$ and Gordon H. Rodda ${ }^{2}$
}

\begin{abstract}
Although it is generally accepted that introduced small mammals have detrimental effects on island ecology, our understanding of these effects is frequently limited by incomplete knowledge of small mammal distribution, density, and biomass. Such information is especially critical in the Mariana Islands, where small mammal density is inversely related to effectiveness of Brown Tree Snake (Boiga irregularis) control tools, such as mouse-attractant traps. We used mark-recapture sampling to determine introduced small mammal distribution, density, and biomass in the major habitats of Guam, Rota, Saipan, and Tinian, including grassland, Leucaena forest, and native limestone forest. Of the five species captured, Rattus diardii (sensu Robins et al. 2007) was most common across habitats and islands. In contrast, Mus musculus was rarely captured at forested sites, Suncus murinus was not captured on Rota, and $R$. exulans and $R$. norvegicus captures were uncommon. Modeling indicated that neophobia, island, sex, reproductive status, and rain amount influenced $R$. diardii capture probability, whereas time, island, and capture heterogeneity influenced $S$. murinus and $M$. musculus capture probability. Density and biomass were much greater on Rota, Saipan, and Tinian than on Guam, most likely a result of Brown Tree Snake predation pressure on the latter island. Rattus diardii and M. musculus density and biomass were greatest in grassland, whereas S. murinus density and biomass were greatest in Leucaena forest. The high densities documented during this research suggest that introduced small mammals (especially $R$. diardii) are impacting abundance and diversity of the native fauna and flora of the Mariana Islands. Further, Brown Tree Snake control and management tools that rely on mouse attractants will be less effective on Rota, Saipan, and Tinian than on Guam. If the Brown Tree Snake becomes established on these islands, high-density introduced small mammal populations will likely facilitate and support a high-density Brown Tree Snake population, even as native species are reduced or extirpated.
\end{abstract}

INTRODUCED SMALL mammals, especially Rattus species, often have detrimental effects on island ecology. Direct effects include competition with, or predation on, amphibian,

\footnotetext{
${ }^{1}$ Funding for this research was provided by the U.S. Department of the Interior, Office of Insular Affairs. Manuscript accepted 13 May 2008.

${ }^{2}$ U.S. Geological Survey, Fort Collins Science Center, 2150 Centre Avenue, Building C, Fort Collins, Colorado 80526-8118.

${ }^{3}$ Corresponding author (phone: 970-226-9489; e-mail: yackela@usgs.gov).
}

Pacific Science (2009), vol. 63, no. 2:205-222

(C) 2009 by University of Hawai'i Press

All rights reserved avian, invertebrate, mammalian, plant, and reptilian species, often resulting in population declines or even extirpation (reviewed in Atkinson 1985, Towns et al. 2006, Jones et al. 2008). Less apparent indirect effects include disruption of island trophic systems (Fritts and Rodda 1998, Towns 1999) and nutrient cycling (Fukami et al. 2006), modification of vegetative community structure and successional patterns (Campbell and Atkinson 2002), and creation of novel vectors and reservoirs for diseases and parasites (Pickering and Norris 1996, Chanteau et al. 1998).

Despite this growing body of evidence, our understanding of the effects of introduced small mammals on island ecology is far from complete. To provide a framework 
for future research, Parker et al. (1999) proposed that three factors determine the impact of introduced species on island ecosystems: their distribution, density or biomass, and effect per individual or unit biomass. Those authors suggested that distribution, density, and biomass are easier to quantify than the per-individual or unit biomass effect of introduced species (Parker et al. 1999). Although this claim is valid from a procedural standpoint, in practice the distribution, density, and biomass of introduced small mammals are poorly understood on many islands. This lack of knowledge is especially surprising for well-studied island systems, such as the Mariana Islands, infamous for the introduced Brown Tree Snake (Boiga irregularis [Savidge 1987, Fritts and Rodda 1998]). In spite of considerable research effort associated with controlling the Brown Tree Snake on Guam and preventing its spread to other vulnerable locations (Colvin et al. 2005), relatively little is known about introduced small mammals in the Mariana Islands, limiting our ability to investigate their effect on both the ecology of the Mariana Islands and Brown Tree Snake control and management.

Based on studies elsewhere in the Pacific, the Mariana Islands have a suite of native species potentially vulnerable to introduced small mammals, including bats, birds, invertebrates, plants, and reptiles, yet putative impacts have not been evaluated in the Mariana Islands despite the large proportion of species declining or endangered without a clear cause (e.g., Fancy and Snetsinger 2001, U.S. Fish and Wildlife Service 2005). Attempts to use historic data to investigate introduced small mammal distribution, density, and biomass in the Mariana Islands are complicated by the common reliance on nonrigorous sampling techniques, such as low sampling effort and convenience sampling (Anderson 2001, 2003), and the frequent dependence on indices of density. As a result, retrospective comparisons across sites, habitats, or islands require unrealistic assumptions about the equality of capture probability across space and time (Anderson 2001, 2003). Thus, our objectives were to: (1) determine the distribution of introduced small mammals across the major habitats of Guam and the nearby islands of Rota, Saipan, and Tinian, and (2) generate robust estimates of density and biomass using rigorous and repeatable markrecapture livetrapping methods.

\section{MATERIALS AND METHODS}

\section{Study Area}

The Mariana Islands consist of 15 islands arrayed in a north-south arc between 13 and $21^{\circ} \mathrm{N}$ and 144 and $146^{\circ} \mathrm{E}$. The marine tropical climate of the Mariana Islands results in minimal seasonal temperature variation, with monthly averages ranging from $24^{\circ} \mathrm{C}$ to $27^{\circ} \mathrm{C}$ (Mueller-Dombois and Fosberg 1998). Precipitation is seasonal, with a rainy season from July to October, and averages 2,0002,500 mm/yr (Mueller-Dombois and Fosberg 1998).

Our study occurred on the islands of Guam, Rota, Saipan, and Tinian. Geologically, these islands consist of upraised coral plateaus and weathered volcanic substrates. The dominant native vegetative community of the coral substrate is limestone forest, which is most common and least disturbed on Rota (Falanruw et al. 1989). These forests have highly variable structure and species composition, primarily as a function of slope, aspect, and elevation as well as the frequency and extent of typhoon damage and human disturbance (Mueller-Dombois and Fosberg 1998). Common limestone forest species include Aglaia mariannensis, Artocarpus mariannensis, Cycas circinalis, Cynometra ramiflora, Elaeocarpus joga, Ficus prolixa, Guamia mariannae, Ochrosia mariannensis, Pandanus dubius and P. tectorius, Pisonia grandis, and Premna obtusifolia (Mueller-Dombois and Fosberg 1998). Many disturbed areas have been colonized by the introduced leguminous tree Leucaena leucocephala, especially on Guam, Saipan, and Tinian. This species often exists in nearly monotypic stands but is also found in association with Flagellaria indica, Hibiscus tiliaceus, Nephrolepis biserrata and N. hirsutula, and Triphasia trifolia (Mueller-Dombois and Fosberg 1998). Areas of exposed volcanic substrate are typically covered by grasslands 
or sparsely forested savannas, especially in southern Guam, the Sabana region of Rota, and the central ridge of Saipan. These habitats are generally dominated by Dimeria chloridiformis, Miscanthus floridulus, or Pennisetum polystachyon (Mueller-Dombois and Fosberg 1998). On Tinian, nonforested areas are generally covered by invasive weeds, especially Mimosa invisa (Mueller-Dombois and Fosberg 1998).

\section{Site Selection}

Between April 2005 and June 2007, we sampled eight sites on Guam (one of which was sampled annually), four sites on Rota, five sites on Saipan, and three sites on Tinian (Table 1). On each island, we identified potential study sites based on habitat type and available area of relatively homogeneous habitat using $1: 24,000$ and $1: 25,000$ scale U.S.
Geological Survey topographical maps and $1: 20,000$ scale vegetation maps (Falanruw et al. 1989). We selected sites in three major habitat types: native limestone forest (hereafter native forest), L. leucocephala-dominated forest (hereafter Leucaena forest), and grassland. Additional sites were selected near airports and seaports, which are critical areas for control and management efforts aimed at preventing Brown Tree Snake transport from Guam to other locations. These sites generally included a mixture of habitats (typically grassland and Leucaena forest) and were classified as mixed habitat. With the exception of mixed habitat, sites contained at least 4 ha of relatively homogeneous habitat. On each island, we sampled at least one native forest site, one grassland site, and one Leucaena forest site. Five sites were sampled near airports and seaports on Guam $(n=2)$, Rota $(n=1)$, and Saipan $(n=2)$ (Table 1).

\section{TABLE 1}

Introduced Small Mammal Sampling Coordinates and Dates on Guam, Rota, Saipan, and Tinian, 2005-2007

\begin{tabular}{|c|c|c|c|}
\hline Site & Dates Sampled & Latitude & Longitude \\
\hline \multicolumn{4}{|l|}{ Guam } \\
\hline Grassland & 6-10 June 2005 & 13.542 & 144.912 \\
\hline Leucaena forest 1 & 30 May-3 June 2005 & 13.512 & 144.870 \\
\hline Leucaena forest 2 & 20-24 June 2005 & 13.417 & 144.783 \\
\hline Leucaena forest 3 & 6-10 Nov. 2006 & 13.437 & 144.659 \\
\hline \multirow{3}{*}{ Leucaena forest 4} & 2-6 May 2005 & 13.640 & 144.865 \\
\hline & 15-19 May 2006 & & \\
\hline & 6-16 June 2007 & & \\
\hline Mixed & 23-27 Oct. 2006 & 13.491 & 144.795 \\
\hline Native forest 1 & 18-22 Apr. 2005 & 13.648 & 144.863 \\
\hline Native forest 2 & 16-20 May 2005 & 13.378 & 144.672 \\
\hline \multicolumn{4}{|l|}{ Rota } \\
\hline Grassland & 23-27 Jan. 2006 & 14.140 & 145.191 \\
\hline Leucaena forest & 30 Jan.-3 Feb. 2006 & 14.115 & 145.199 \\
\hline Mixed & 10-14 Apr. 2006 & 14.170 & 145.240 \\
\hline Native forest & 3-7 Apr. 2006 & 14.154 & 145.170 \\
\hline \multicolumn{4}{|l|}{ Saipan } \\
\hline Grassland & 19-23 Sep. 2005 & 15.238 & 145.773 \\
\hline Leucaena forest & 26-30 Sep. 2005 & 15.108 & 145.729 \\
\hline Mixed 1 & 15-19 Aug. 2006 & 15.227 & 145.744 \\
\hline Mixed 2 & 22-26 Aug. 2006 & 15.127 & 145.727 \\
\hline Native forest & $12-16$ Sep. 2005 & 15.251 & 145.798 \\
\hline \multicolumn{4}{|l|}{ Tinian } \\
\hline Grassland & 24-28 Oct. 2005 & 14.951 & 145.651 \\
\hline Leucaena forest & $7-11$ Nov. 2005 & 15.076 & 145.640 \\
\hline Native forest & 31 Oct.-4 Nov. 2005 & 15.043 & 145.629 \\
\hline
\end{tabular}




\section{Small Mammal Sampling}

The introduced small mammal community of the Mariana Islands consists of at least five species, ranging from the earliest introduction, Rattus exulans, which occurred no later than AD 1000-1200 (Steadman 1999), to the most recent introduction, Suncus murinus, first documented on Guam in 1953 (Peterson 1956). Other introductions include Mus musculus, first reported on Guam in 1819 (Freycinet 2003), and R. norvegicus, first reported on Saipan in the late 1800s (Kuroda 1938). Due to the uncertainty surrounding the identity of a third Rattus species, thought to be either $R$. rattus or $R$. tanezumi, two morphologically similar species only recently separated based on karyotypic differences (Musser and Carleton 2005), we collected genetic material from all captured Rattus. Preliminary genetic analysis (S. J. Oyler-McCance and J. St. John, unpubl. data) of randomly selected samples from Guam $(n=17)$, Rota $(n=10)$, Saipan $(n=10)$, and Tinian $(n=10)$ indicated that all were most closely related to the $R$. diardii group described by Robins et al. (2007). Until taxonomic identity of this group is resolved, we refer to them here as $R$. diardii.

At each site, we conducted mark-recapture livetrapping for five consecutive nights on an $11 \times 11$ grid with $12.5 \mathrm{~m}$ intervals between each trap station $(1.56 \mathrm{ha})$. We placed a single standard-length folding Sherman live trap $(229 \times 89 \times 76 \mathrm{~mm}[\mathrm{H} . \mathrm{B}$. Sherman Traps, Inc., Tallahassee, Florida]) at each trap station $(n=121)$ and a single Haguruma wire mesh live trap $(285 \times 210 \times 140 \mathrm{~mm}$ [Standard Trading Co., Honolulu, Hawai'i]) at every other trap station $(n=36)$. Trap selection and spacing were determined through preliminary testing and literature review of target species' home range and movement patterns, with the goal of maximizing captures. Sherman traps, which best captured M. musculus and S. murinus during preliminary testing, were spaced at $12.5 \mathrm{~m}$ intervals to match the relatively small home ranges of these species in the Mariana Islands (Baker 1946, Barbehenn 1969, 1974a). Haguruma traps, which best captured Rattus species during preliminary testing, were spaced at $25 \mathrm{~m}$ intervals to better match the larger home ranges of these species in the Mariana Islands (Baker 1946, Barbehenn 1969, 1974a).

We placed closed traps on the grid two nights before the beginning of sampling to provide an opportunity for small mammals to acclimate to their presence. Traps were placed on the ground and, whenever possible, positioned to provide shelter from sun and rain. Traps were baited with a mixture of peanut butter, oats, and food-grade paraffin and were checked beginning at $0730-0800$ hours each day. Traps were closed during the day to minimize trap mortality, reopened at approximately 1600 hours, and rebaited as necessary.

We uniquely marked captured animals on each ear with numbered metal tags (M. musculus and S. murinus: small ear tags produced by S. Roestenburg, Riverton, Utah; Rattus species: no. 1005-1, National Band and Tag Co., Newport, Kentucky). We examined and measured captured animals to determine species, sex, age, reproductive status, mass (g), head-body length $(\mathrm{mm})$, tail length $(\mathrm{mm})$, right hind foot length (mm), right ear length $(\mathrm{mm})$, and testes length ( $\mathrm{mm}$, if applicable). Capture, handling, and marking techniques followed guidelines approved by the American Society of Mammalogists (Gannon et al. 2007) and the U.S. Geological Survey Animal Care and Use Committee (Fort Collins Science Center).

We also sampled each site (except for Leucaena forest 4 [Table 1]) with five consecutive nights of snaptrapping during the week following livetrapping. A comparison of livetrapping and snaptrapping will be published elsewhere; however, snaptrapping data were included in the calculation of body condition index and mean maximum distance moved. We also used snaptrapping data to evaluate the effectiveness of our livetrapping methodology. One concern with relatively shortduration sampling is that rare or nondominant species may not be captured (Brown et al. 1996, Harper and Veitch 2006). We documented only three instances (out of 43 possible) where species not captured during livetrapping were captured during snaptrapping. Twice, a single individual (one $M$. 
musculus and one $R$. diardii) was captured and in the other instance five $S$. murinus were captured. Five of these seven captures occurred on the grid perimeter, suggesting snaptrapping-induced immigration (Stickel 1946) rather than species missed by livetrapping.

\section{Data Analysis}

We estimated density and biomass separately for each species. First, we generated sitespecific estimates of abundance using estimated capture and recapture probability modeled from livetrapping data. Second, we estimated effective trapping area for each site with reference to each species' mean maximum distance moved between captures. Third, we calculated density as abundance/ effective trapping area. Fourth, we determined site-specific mean body mass. Fifth, we calculated biomass as the product of sitespecific density and mean body mass.

Data analysis followed an informationtheoretic approach involving model selection and multimodel inference. Model selection was based on Akaike's Information Criterion corrected for small sample size AIC $_{c}$ [Burnham and Anderson 2002]). Models were considered competitive with the top-ranked model when $\Delta \mathrm{AIC}_{\mathrm{c}} \leq 2.0$ (Burnham and Anderson 2002). Model averaging was based on Akaike weights ( $w_{\mathrm{i}}$ [Burnham and Anderson 2002]) and included the entire model set except for models with nonsensical $\beta$ estimates (e.g., $\beta=16.8, \operatorname{SE}(\beta)=2,084.6$ ). Unless otherwise indicated, estimates are presented as mean $\pm 1 \mathrm{SE}$.

MODELING CAPTURE AND RECAPTURE рвовавіLITy. We generated model-averaged abundance estimates (Burnham and Anderson 2002) in Program MARK 4.3 (White and Burnham 1999) using the conditional likelihood closed capture-recapture model developed by Huggins (1989, 1991). This model uses estimates of capture probability and the number of individuals captured to estimate abundance and can account for heterogeneity in capture probability from temporal, behavioral, and individual effects (expressed as either unexplained heterogene- ity (i.e., finite mixture distributions [Pledger 2000]) or covariate-associated capture heterogeneity [Huggins 1989, 1991]).

In Program MARK, we coded design matrices to allow sites to be treated both individually and as groups, based on common attributes such as island or habitat. Capture and recapture probability were primarily modeled across these groups to increase statistical efficiency (i.e., reduce estimate variance) and allow abundance estimates to be generated from sites with few captures or recaptures (Bowden et al. 2003). We specified models in an iterative fashion, beginning with models allowing capture probability to vary by time $(\mathrm{t})$, behavior (b), individuals (i.e., capture heterogeneity, h), combinations of these factors, or constraining capture probability to be constant. We specified models incorporating capture heterogeneity as two-mixture models, based on concerns that our dataset would not support a more parameterized mixture model (Conn et al. 2006). If the top model included temporal variation, we fit a set of neophobia models to the dataset. Neophobia models allowed capture probability to vary during the first (neo1) or first and second (neo2) sampling occasions, while holding capture probability constant for the remaining occasions. Motivation for these models came from literature accounts of neophobia for Rattus (Temme and Jackson 1979, Inglis et al. 1996, Clapperton 2006). The next subset of models was parameterized to model capture probability, recapture probability, or both capture and recapture probability as a function of island, habitat, or site. We hypothesized that capture probability would differ between Guam (with brown tree snakes) and Rota, Saipan, and Tinian (without established Brown Tree Snake populations), so the island grouping was coded in two ways, with island[4] distinguishing each island and island[2] distinguishing Guam from the combination of Rota, Saipan, and Tinian.

Our final subset of models incorporated covariates, beginning with the global model and proceeding to more parsimonious models. Covariates under consideration included sex (male or female), age (adult or juvenile), reproductive status, body condition index, 
body size, rain previous night, and rain amount. Reproductive status (repstat) was a categorical variable differentiating reproductively active adults from nonreproductive adults and juveniles; we assigned repstat class based on mass and the presence of externally visible sexual characteristics such as descended testes for males and active lactation for females. We calculated body condition index (bodycon) as the ratio between the observed and expected mass of an individual, where expected mass was determined from a linear regression of $\ln$ mass versus $\ln$ headbody length. For each species, we modeled variation in bodycon as a function of island[4], island[2], and habitat in an analysis of variance framework (Proc GLM [SAS Institute, Inc., Cary, North Carolina]). We then included bodycon estimates from the top model (or model-averaged bodycon) in covariate models. Body Size (size) was a speciesspecific composite variable created from a principal components analysis (Proc FACTOR [SAS Institute, Inc.]) of mass, headbody length, tail length, hind foot length, and ear length measured for each individual. We also included rain previous night (rainprev), a categorical measure of the presence or absence of rainfall during each trap night, and rain amount (rainamt), a quantitative measure of total rainfall $(\mathrm{mm})$ at the center of each trapping grid. Our rainamt measurements encompassed a 24-hr period, with the exception of the first sampling occasion, for which rainamt included only the 12- to 16-hr period before trap monitoring. Before including rainamt, we determined that rainfall from the first sampling occasion did not differ appreciably from rainfall on other occasions based on overlapping $95 \%$ confidence intervals.

DENSITY AND BIOMASS ESTIMATION. For each site, we calculated species-specific density by dividing the model-averaged abundance estimates by effective trapping area, where effective trapping area equaled the total area encompassed by the trapping grid (1.56 ha) plus a boundary strip of half the mean maximum distance moved between captures for individuals captured two or more times (Wilson and Anderson 1985). For each species, variation in mean maximum distance moved was modeled as a function of island[4], island[2], and habitat in an analysis of variance framework (Proc GLM [SAS Institute, Inc.]). Mean maximum distance moved estimates from the top model (or modelaveraged mean maximum distance moved) were used in density calculations. For each site, we calculated species-specific biomass as the product of density and mean body mass. We used the mean mass of individuals captured two or more times in calculations of species-specific mean body mass. We calculated the variance of density and biomass estimates using the delta method (Seber 2002).

\section{RESULTS}

We captured $707 R$. diardii, 298 S. murinus, 154 M. musculus, $16 R$. exulans, and five $R$. norvegicus in 17,270 trap nights. Of these, $R$. diardii was most common across habitats and islands (Table 2). In contrast, S. murinus was not captured on Rota (Table 3) and M. musculus was rarely captured at forested sites (Table 4). $R$. exulans and $R$. norvegicus were captured at only four sites each and will not be considered further. In general, captures of all species were greater on Rota, Saipan, and Tinian than on Guam.

\section{Modeling Capture and Recapture Probability}

$R$. diardii capture and recapture probability were best explained by an additive model $\left(w_{\mathrm{i}}=0.871\right.$ [Table 5]) allowing neophobia (neo2) in capture probability for each island (island[4]), as well as capture probability variation by sex, repstat, and rainamt with recapture probability varying similarly by island[4], sex, repstat, and rainamt. Reproductively active females were more than twice as likely to be captured as nonreproductive males (Figure 1), and captures of all individuals increased with increasing rainfall. All plausible models contained the neo 2 effect on capture probability; the top model without neo2 had no support $\left(\Delta \mathrm{AIC}_{\mathrm{c}}=33.92\right)$. All covariate effects were strong based on $95 \%$ confidence intervals that excluded zero.

Suncus murinus capture and recapture 
TABLE 2

Number of Individuals $\left(M_{t+1}\right)$ and Total $(n$.$) Rattus diardii Captures, Density (\hat{D}$ [animals/ha]) and Biomass Estimates (Biom $[\mathrm{kg} / \mathrm{ha}])$, and Associated Standard Errors (SE) and 95\% Confidence Intervals (95\% CI) during Livetrapping in Grassland, Leucaena Forest, Mixed, and Native Forest Habitats on Guam, Rota, Saipan, and Tinian, 2005-2007

\begin{tabular}{|c|c|c|c|c|c|c|c|c|}
\hline Site & $M_{t+1}$ & $n$ & $\hat{D}$ & SE & $95 \% \mathrm{CI}$ & $\widehat{B i o m}$ & SE & $95 \%$ CI \\
\hline \multicolumn{9}{|l|}{ Guam $^{a}$} \\
\hline Grassland & 22 & 24 & 15.9 & 3.7 & $8.6-23.2$ & 2.42 & 0.58 & $1.28-3.56$ \\
\hline Leucaena forest 1 & 5 & 6 & 2.6 & 0.7 & $1.2-4.0$ & 0.70 & 0.19 & $0.33-1.07$ \\
\hline Leucaena forest 3 & 13 & 14 & 8.9 & 2.3 & $4.4-13.4$ & 1.36 & 0.37 & $0.63-2.09$ \\
\hline \multirow[t]{2}{*}{ Leucaena forest $4^{b}$} & 4 & 4 & 2.6 & 1.0 & $0.6-4.6$ & 0.39 & 0.16 & $0.08-0.70$ \\
\hline & 22 & 27 & 15.3 & 3.5 & $8.4-22.2$ & 2.88 & 0.66 & $1.59-4.17$ \\
\hline Mixed & 1 & 1 & 0.7 & 0.5 & $0-1.7$ & 0.06 & 0.05 & $0-0.16$ \\
\hline \multicolumn{9}{|l|}{ Rota } \\
\hline Grassland & 88 & 119 & 73.2 & 11.9 & $49.9-96.5$ & 9.80 & 1.62 & $6.62-12.98$ \\
\hline Leucaena forest & 42 & 63 & 36.0 & 6.7 & $22.9-49.1$ & 4.63 & 0.89 & $2.89-6.37$ \\
\hline Mixed & 106 & 146 & 95.8 & 16.1 & $64.2-127.4$ & 8.85 & 1.54 & $5.83-11.87$ \\
\hline Native forest & 11 & 11 & 9.2 & 2.2 & $4.9-13.5$ & 1.03 & 0.28 & $0.48-1.58$ \\
\hline \multicolumn{9}{|l|}{ Saipan } \\
\hline Grassland & 41 & 63 & 33.0 & 6.4 & $20.5-45.5$ & 4.13 & 0.83 & $2.50-5.76$ \\
\hline Leucaena forest & 50 & 58 & 41.4 & 8.1 & $25.5-57.3$ & 4.31 & 0.87 & $2.60-6.02$ \\
\hline Mixed 1 & 29 & 34 & 25.1 & 5.4 & $14.5-35.7$ & 3.03 & 0.68 & $1.70-4.36$ \\
\hline Mixed 2 & 8 & 8 & 6.9 & 2.1 & $2.8-11.0$ & 0.96 & 0.32 & $0.33-1.59$ \\
\hline Native forest & 24 & 28 & 21.6 & 5.1 & $11.6-31.6$ & 3.18 & 0.76 & $1.69-4.67$ \\
\hline \multicolumn{9}{|l|}{ Tinian } \\
\hline Grassland & 106 & 132 & 99.9 & 17.9 & $64.8-135.0$ & 11.57 & 2.11 & $7.43-15.71$ \\
\hline Leucaena forest & 55 & 81 & 44.0 & 7.3 & $29.7-58.3$ & 5.09 & 0.88 & $3.37-6.81$ \\
\hline Native forest & 80 & 92 & 75.1 & 13.6 & $48.4-101.8$ & 8.78 & 1.63 & $5.59-11.97$ \\
\hline
\end{tabular}

a Zero $R$. diardii captured at three sites (one Leucaena forest and two native forest).

${ }^{b}$ Zero R. diardii captured during 2007 sampling at Leucaena forest 4.

\section{TABLE 3}

Number of Individuals $\left(M_{t+1}\right)$ and Total (n.) Suncus murinus Captures, Density $(\hat{D}$ [animals/ha]) and Biomass Estimates (Biom $[\mathrm{kg} / \mathrm{ha}])$, and Associated Standard Errors (SE) and 95\% Confidence Intervals (95\% CI) during Livetrapping in Grassland, Leucaena Forest, Mixed, and Native Forest Habitats on Guam, Saipan, and Tinian, 2005-2007

\begin{tabular}{|c|c|c|c|c|c|c|c|c|}
\hline Site & $M_{t+1}$ & $n$ & $\hat{D}$ & SE & $95 \%$ CI & $\widehat{B i o m}$ & SE & $95 \% \mathrm{CI}$ \\
\hline \multicolumn{9}{|l|}{ Guam $^{a}$} \\
\hline Grassland & 14 & 22 & 8.6 & 2.5 & $3.7-13.5$ & 0.20 & 0.06 & $0.08-0.32$ \\
\hline \multicolumn{9}{|l|}{ Saipan } \\
\hline Grassland & 19 & 41 & 13.4 & 3.7 & $6.1-20.7$ & 0.24 & 0.08 & $0.08-0.40$ \\
\hline Leucaena forest & 43 & 63 & 31.6 & 10.2 & $11.6-51.6$ & 0.88 & 0.27 & $0.35-1.41$ \\
\hline Mixed 1 & 9 & 9 & 6.3 & 2.2 & $2.0-10.6$ & 0.18 & 0.06 & $0.06-0.30$ \\
\hline Mixed 2 & 47 & 59 & 32.9 & 9.6 & $14.1-51.7$ & 0.98 & 0.28 & $0.43-1.53$ \\
\hline Native forest & 19 & 21 & 14.0 & 5.2 & $3.8-24.2$ & 0.40 & 0.13 & $0.15-0.66$ \\
\hline \multicolumn{9}{|l|}{ Tinian } \\
\hline Grassland & 11 & 11 & 8.9 & 2.5 & $4.0-13.8$ & 0.16 & 0.05 & $0.06-0.26$ \\
\hline Leucaena forest & 93 & 113 & 73.7 & 20.1 & $34.3-113.1$ & 1.87 & 0.52 & $0.85-2.89$ \\
\hline Native forest & 43 & 43 & 32.8 & 9.6 & $14.0-51.6$ & 0.83 & 0.25 & $0.34-1.32$ \\
\hline
\end{tabular}

Note: S. murinus was neither captured nor observed on Rota.

a Zero S. murinus captured at seven sites (four Leucaena forest, one mixed habitat, and two native forest). 
TABLE 4

Number of Individuals $\left(M_{t+1}\right)$ and Total (n.) Mus musculus Captures, Density $(\hat{D}[$ animals/ha] $)$ and Biomass Estimates (Biom $[\mathrm{kg} / \mathrm{ha}]$ ), and Associated Standard Errors (SE) and 95\% Confidence Intervals (95\% CI) during Livetrapping in Grassland, Leucaena Forest, Mixed, and Native Forest Habitats on Guam, Rota, Saipan, and Tinian, 2005-2007

\begin{tabular}{|c|c|c|c|c|c|c|c|c|}
\hline Site & $M_{t+1}$ & $n$ & $\hat{D}$ & $\mathrm{SE}$ & $95 \%$ CI & $\widehat{B i o m}$ & SE & $95 \%$ CI \\
\hline \multicolumn{9}{|l|}{ Guam $^{a}$} \\
\hline Grassland & 15 & 29 & 7.2 & 1.7 & $3.9-10.5$ & 0.08 & 0.02 & $0.04-0.12$ \\
\hline \multicolumn{9}{|l|}{ Rota } \\
\hline Grassland & 25 & 32 & 20.7 & 5.0 & $10.9-30.5$ & 0.26 & 0.07 & $0.12-0.40$ \\
\hline Leucaena forest & 19 & 27 & 16.0 & 4.1 & $8.0-24.0$ & 0.20 & 0.05 & $0.10-0.30$ \\
\hline Mixed & 32 & 51 & 26.5 & 6.3 & $14.2-38.8$ & 0.34 & 0.08 & $0.18-0.50$ \\
\hline Native forest & 1 & 2 & 0.8 & 0.6 & $0-2.0$ & 0.01 & 0.01 & $0-0.03$ \\
\hline \multicolumn{9}{|l|}{ Saipan $^{b}$} \\
\hline Grassland & 51 & 96 & 36.5 & 8.1 & $20.6-52.4$ & 0.45 & 0.10 & $0.25-0.65$ \\
\hline Leucaena forest & 2 & 2 & 1.5 & 0.7 & $0.1-2.9$ & 0.01 & 0.01 & $0-0.03$ \\
\hline \multicolumn{9}{|l|}{$\operatorname{Tinian}^{c}$} \\
\hline Grassland & 9 & 12 & 8.2 & 2.7 & $2.9-13.5$ & 0.11 & 0.04 & $0.03-0.19$ \\
\hline
\end{tabular}

a Zero M. musculus captured at seven sites (four Leucaena forest, one mixed habitat, and two native forest).

${ }^{b}$ Zero M. musculus captured at three sites (two mixed habitat and one native forest).

c Zero M. musculus captured at two sites (one Leucaena forest and one native forest).

TABLE 5

Model Selection Results for Mark-Recapture Modeling of Capture ( $p$ ) and Recapture ( $c$ ) Probability for Rattus diardii, Suncus murinus, and Mus musculus Livetrapping Data Collected on Guam, Rota, Saipan, and Tinian, 2005-2007

\begin{tabular}{|c|c|c|c|}
\hline & $K$ & $\Delta \mathrm{AIC}_{\mathrm{c}}$ & $w_{\mathrm{i}}$ \\
\hline \multicolumn{4}{|l|}{ Models for $R$. diardii } \\
\hline$p_{\text {neo2 } 2 \text { island }[4])+ \text { sex }+ \text { repstat }+ \text { rainamt }} c_{\text {island }[4]+\text { sex }+ \text { repstat+rainamt }}$ & 16 & 0.00 & 0.871 \\
\hline$p_{\text {neo2 }(\text { island[4]) }+ \text { repstat }+ \text { rainamt }} c_{\text {island }[4]+\text { repstat }+ \text { rainamt }}$ & 15 & 5.72 & 0.050 \\
\hline$p_{\text {neo } 2(\text { island }[4])+\text { sex }+ \text { age }+ \text { repstat }+ \text { bodycon }+ \text { size }+ \text { rainprev }+ \text { rainamt }}$ & 20 & 6.97 & 0.027 \\
\hline$c_{\text {island }[4]+\text { sex }+ \text { age }+ \text { repstat }+ \text { bodycon }+ \text { size }+ \text { rainprev }+ \text { rainamt }}$ & & & \\
\hline$p_{\text {neo2 }(\text { island }[4])+\text { sex }+ \text { rainamt }} c_{\text {island }[4]+\text { sex }+ \text { rainamt }}$ & 15 & 7.12 & 0.025 \\
\hline$p_{\text {neo2 }(\text { island }[4])+\text { rainamt }} c_{\text {island }[4]+\text { rainamt }}$ & 14 & 7.56 & 0.020 \\
\hline$p_{\text {neo2 }(\text { island }[4])+\text { sex }+ \text { repstat }} c_{\text {island }[4]+\text { sex }+ \text { repstat }}$ & 15 & 9.61 & 0.007 \\
\hline \multicolumn{4}{|l|}{ Models for S. murinus } \\
\hline$p_{\mathrm{t}+\mathrm{h}} c_{\mathrm{t}(\text { island }[4])+\mathrm{h}}$ & 10 & 0.00 & 0.994 \\
\hline$p_{\mathrm{t}+\mathrm{h}+\text { sex }}+$ repstat+bodycon+size+rainprev+rainamt & 16 & 10.33 & 0.006 \\
\hline$c_{\mathrm{t}(\text { island }[4])+\mathrm{h}+\text { sex }+ \text { repstat }+ \text { bodycon }+ \text { size }+ \text { rainprev }+ \text { rainamt }}$ & & & \\
\hline \multicolumn{4}{|l|}{ Models for M. musculus } \\
\hline$p_{\mathrm{t}(\text { island[2]) }+\mathrm{h}} c_{\mathrm{t}+\mathrm{h}}$ & 11 & 0.00 & 0.349 \\
\hline$p_{\mathrm{t}(\text { island[2] })+\mathrm{h}} c_{\mathrm{t}(\text { island[2])+h}}$ & 13 & 0.10 & 0.331 \\
\hline$p_{\mathrm{t}(\text { island }[4])+\mathrm{h}} c_{\mathrm{t}+\mathrm{h}}$ & 19 & 1.20 & 0.192 \\
\hline$p_{\mathrm{t}+\mathrm{h}} c_{\mathrm{t}(\mathrm{island}[2])+\mathrm{h}}$ & 9 & 4.36 & 0.039 \\
\hline$p_{\mathrm{t}(\text { island }[4])+\mathrm{h}} c_{\mathrm{t}(\mathrm{island}[4])+\mathrm{h}}$ & 23 & 4.65 & 0.034 \\
\hline$p_{\mathrm{t}+\mathrm{h}} c_{\mathrm{t}+\mathrm{h}}$ & 7 & 5.01 & 0.029 \\
\hline$p_{\text {neol }+\mathrm{h}} c_{\mathrm{h}}$ & 4 & 6.79 & 0.012 \\
\hline$p_{\mathrm{t}+\mathrm{h}} c_{\mathrm{t}(\text { habitat })+\mathrm{h}}$ & 11 & 7.94 & 0.007 \\
\hline$p_{\text {neo } 2+\mathrm{h}} c_{\mathrm{h}}$ & 5 & 8.82 & 0.004 \\
\hline$p_{\mathrm{t}(\text { island }[2])+\mathrm{h}+\mathrm{sex}+\text { repstat }+ \text { bodycon }+ \text { size }+ \text { rainprev }+ \text { rainamt }}$ & 17 & 9.23 & 0.003 \\
\hline$c_{\mathrm{t}+\mathrm{h}+\text { sex }+ \text { repstat+bodycon+size }+ \text { rainprev +rainamt }}$ & & & \\
\hline
\end{tabular}

Note: Parenthetical terms indicate the nesting structure of the previous variable (e.g., neo2(island[4]) specifies separate two-day neophobia effects for each of four islands). All heterogeneity models (h) used two mixtures to approximate individual heterogeneity. Results include the number of model parameters $(K)$, relative Akaike's Information Criterion corrected for small sample size $\left(\Delta \mathrm{AIC}_{\mathrm{c}}\right)$, and Akaike weight $\left(w_{\mathrm{i}}\right)$. 

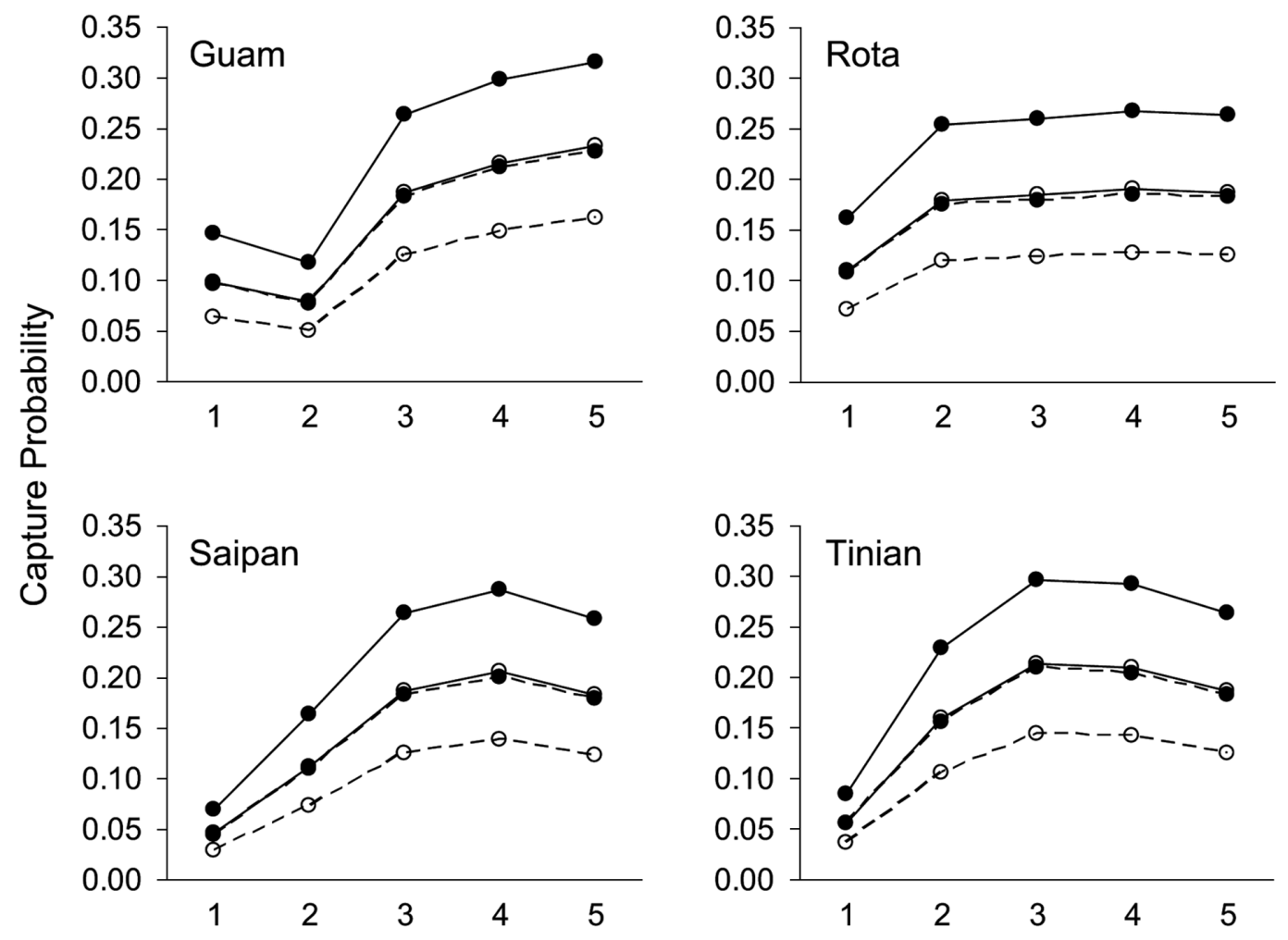

\section{Occasion}

Figure 1. Effect of neophobia (reduced capture probability during occasions 1 and 2), sex (female, •; male, ○), and reproductive status (reproductively active, solid line; nonreproductive, dashed line) on Rattus diardii livetrapping capture probability on Guam, Rota, Saipan, and Tinian, 2005-2007.

probability were best explained by an additive model allowing temporal variation and heterogeneity in capture probability and temporal variation for each island (island[4]) and heterogeneity in recapture probability $\left(w_{i}=0.994\right.$ [Table 5]). The top model without a temporal effect had no support $\left(\Delta \mathrm{AIC}_{\mathrm{c}}=32.43\right)$. Unexplained heterogeneity was approximated by two mixture classes composing $65 \%$ (low capture probability) and $35 \%$ (high capture probability) of the population; over half of the population had estimated daily capture probability $<0.16$ (Figure 2).

M. musculus capture and recapture probability were best explained by three additive models allowing both temporal variation and heterogeneity in these parameters (Table 5).
The top model without a temporal effect had no support $\left(\Delta \mathrm{AIC}_{\mathrm{c}}=15.91\right)$. Unexplained heterogeneity was approximated by two mixture classes composing $67.3 \%$ (low probability) and $32.7 \%$ (high probability) of the population. For Rota, Saipan, and Tinian, over half of the population had estimated daily capture probability $<0.20$, whereas for Guam daily capture probability was generally higher (Figure 2).

Estimates of Maximum Mean Distance Moved

Rattus diardii mean maximum distance moved varied between islands (island[4]; $w_{\mathrm{i}}=0.977$ ) and was greatest on Guam $(35.6 \pm 5.4 \mathrm{~m}$; $n=33)$, followed by Saipan $(22.8 \pm 2.5 \mathrm{~m}$; 


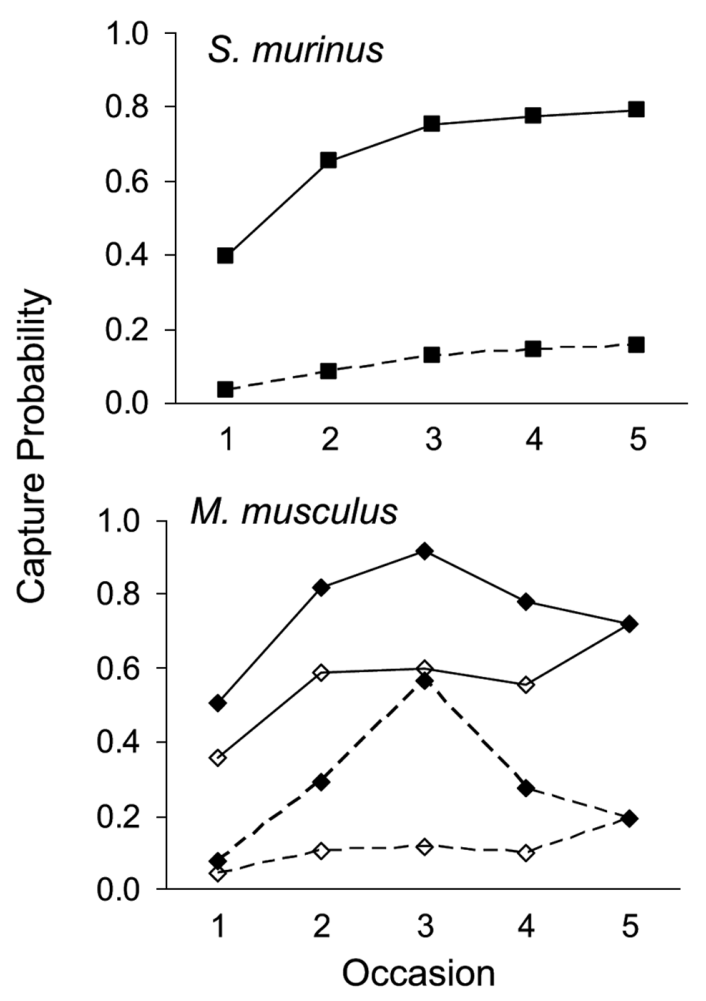

Figure 2. Suncus murinus and Mus musculus mixturespecific capture probability during livetrapping conducted on Guam, Rota, Saipan, and Tinian, 2005-2007. For S. murinus (ם), the high mixture class (solid line) composed $35 \%$ of the population, whereas the low mixture class (dashed line) composed $65 \%$ of the population. Mus musculus mixture-specific capture probabilities differed between Guam $(\diamond)$ and the combination of Rota, Saipan, and Tinian $(\diamond)$, with the high mixture class (solid line) composing $32.7 \%$ of population and the low mixture class (dashed line) composing $67.3 \%$ of the population.

$n=100)$, Rota $(14.5 \pm 1.6 \mathrm{~m} ; n=175)$, and Tinian $(14.5 \pm 1.3 \mathrm{~m} ; n=180)$. Suncus murinus mean maximum distance moved varied between habitats $\left(w_{\mathrm{i}}=0.987\right)$ and was greatest in grassland $(29.2 \pm 2.7 \mathrm{~m} ; n=48)$, followed by mixed habitat $(19.3 \pm 3.2 \mathrm{~m}$; $n=25)$, Leucaena forest $(16.3 \pm 1.4 \mathrm{~m} ; n=$ $68)$, and native forest $(14.2 \pm 3.5 \mathrm{~m} ; n=12)$. Mus musculus mean maximum distance moved varied between islands (island[4]; $w_{\mathrm{i}}=0.718$ ), although there was also support for the simpler island model (island[2]; $w_{\mathrm{i}}=0.272$ ).
Model-averaged mean maximum distance moved was greatest on Guam $(31.2 \pm 3.6 \mathrm{~m}$; $n=25)$, followed by Saipan $(22.8 \pm 2.5 \mathrm{~m}$; $n=77)$, Rota $(18.2 \pm 3.2 \mathrm{~m} ; n=59)$, and Tinian $(11.7 \pm 8.7 \mathrm{~m} ; n=3)$.

\section{Density Estimates}

Mean $R$. diardii density was greatest on Tinian $(73.0 / \mathrm{ha})$, followed by Rota $(53.5 / \mathrm{ha})$ and Saipan (25.6/ha), with much lower values on Guam (5.1/ha) (Table 2). Mean S. murinus density was also much greater on Tinian (38.5/ha) and Saipan (19.6/ha) than on Guam (1.0/ha) (Table 3). Mean M. musculus density was greatest on Rota $(15.8 / \mathrm{ha})$, followed by Saipan (7.7/ha), Tinian (2.6/ha), and Guam (0.8/ha [Table 4]).

\section{Biomass Estimates}

For each species, mean biomass was greater on Rota, Saipan, and Tinian than on Guam (Tables 2-4). On Rota, Saipan, and Tinian, $R$. diardii and $M$. musculus biomass were greatest in grassland (Figure 3), with maximum estimates of $11.6 \mathrm{~kg} / \mathrm{ha}$ and $0.4 \mathrm{~kg} / \mathrm{ha}$, respectively. In contrast, $S$. murinus biomass was highest in Leucaena forest on Saipan and Tinian (Figure 3 ), with a maximum estimate of $1.9 \mathrm{~kg} / \mathrm{h}$. On Guam, mean biomass was greatest in grassland for all species, although moderate levels of $R$. diardii biomass were also observed in Leucaena forest (Figure 3).

\section{DISCUSSION}

We documented high but variable introduced small mammal density and biomass on the islands of Rota, Saipan, and Tinian. Maximum $R$. diardii density estimates on these islands were two to three times greater than historic Rattus estimates from Guam or other tropical Pacific islands, including Pohnpei (4.0-8.5/ha [Strecker 1962]), Majuro (11.3/ha [Strecker 1962]), and Eniwetok (19.9/ha [Jackson 1967]). The high densities observed during our study, especially on Rota and Tinian, could indicate population irruptions. We speculate, however, that our observation of high densities across habitats, islands, and 


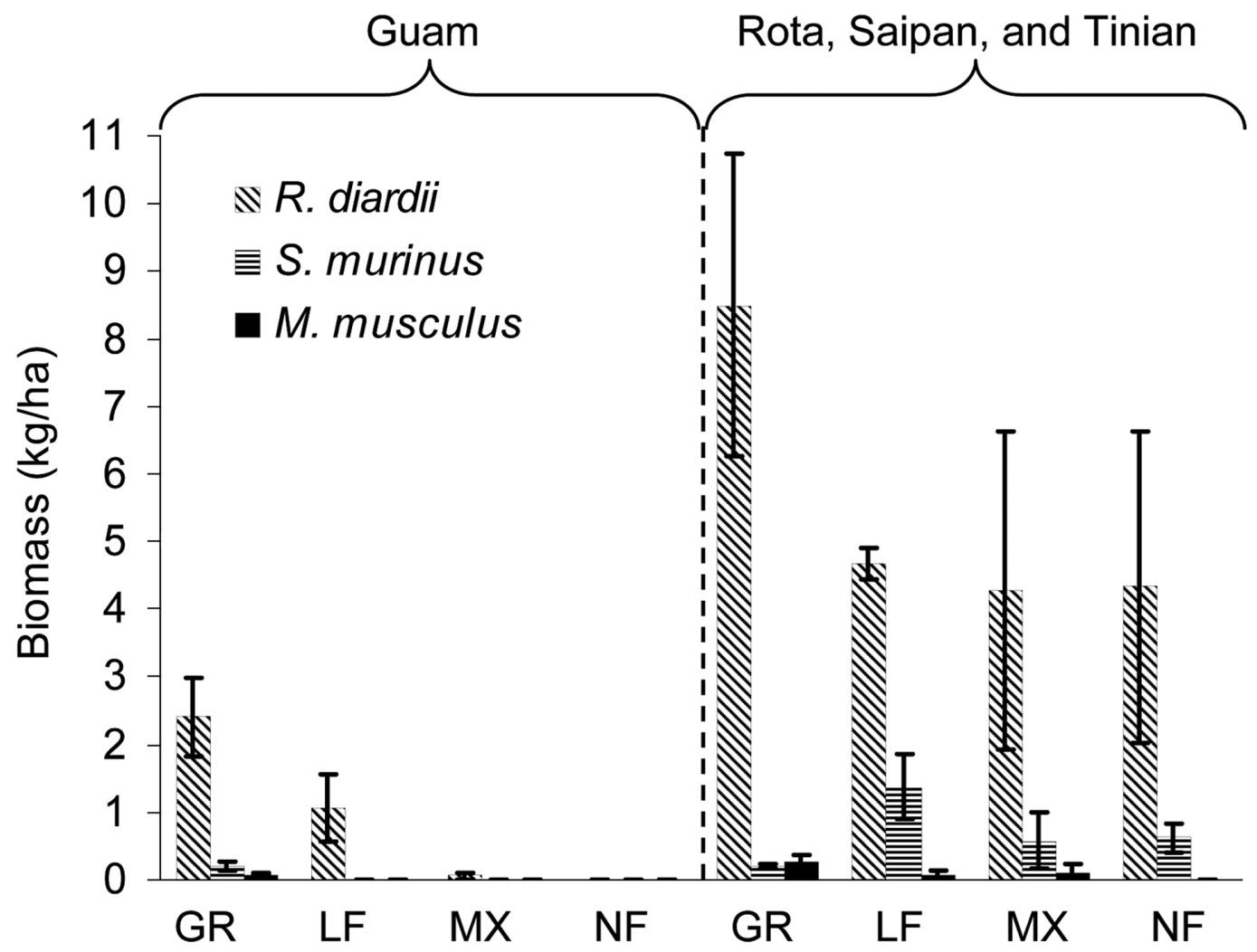

Figure 3. Mean Rattus diardii, Suncus murinus, and Mus musculus biomass estimates derived from mark-recapture livetrapping of grassland (GR), Leucaena forest (LF), mixed (MX), and native forest (NF) habitats on Guam, Rota, Saipan, and Tinian, 2005-2007. Bars indicate \pm 1 SE.

time represent persistent high-density populations. Comparable densities have been recorded for a smaller introduced Rattus species ( $R$. exulans) on small, relatively competitor- and predator-free islands. On Kure Atoll, Wirtz (1972) documented mean $R$. exulans density of $111.2 /$ ha during sampling from March 1964 to May 1965, with monthly estimates of $49.4-185.3 / \mathrm{ha}$. Similarly, on Tiritiri Matangi Island, New Zealand, Moller and Craig (1987) estimated peak $R$. exulans densities of $130 \pm 20 /$ ha in grassland and $101 \pm 12 /$ ha in forest during regular sampling from February 1975 to May 1977. Using mass data provided in Wirtz (1972) and Moller and Craig (1987), these densities translate to biomass of ca. 3.4$8.9 \mathrm{~kg} / \mathrm{ha}$ on Kure Atoll and peak biomass of
9.9 and $6.9 \mathrm{~kg} / \mathrm{ha}$ in grassland and forest, respectively, on Tiritiri Matangi Island.

Our $R$. diardii density and biomass estimates were considerably lower on Guam and were also lower than Guam Rattus estimates from 1945 (10.9-30.0/ha [Baker 1946]) and the early 1960s (18.8/ha [Barbehenn 1969, 1974b]). Our Guam estimates were generally lower in forest than in grassland, a pattern first observed in the 1980s by Savidge (1986; forest: $0-2.5 /$ ha, grassland: 36.4/ha). Gragg (2004) also found high Rattus density (14.7$69.8 / \mathrm{ha}$ ) in grassland in 2002-2003. This pattern is at least partially attributable to variable Brown Tree Snake predation pressure, because snake density is generally greatest in forest on Guam (Savidge 1987, 1991).

Although S. murinus was reported on Rota 
in 1966 (Barbehenn 1974b), we neither captured nor observed this species during 9 weeks on the island. On Saipan and Tinian, $S$. murinus density and biomass were generally greatest in Leucaena forest, whereas we had zero captures at forest sites on Guam, perhaps due to Brown Tree Snake predation pressure in that habitat. In general, our estimates of $S$. murinus density are comparable with historic values from Guam (25.4/ha [Barbehenn 1969, 1974b]; 19.1/ha [Savidge 1986]) and more recent estimates from Saipan (16.7-27.3/ha [S. Vogt, unpubl. data]). Our estimates are also similar to values obtained on Ile aux Aigrettes (29.2/ha) and Ile de la Passe (20/ha), two islands off the coast of Mauritius in the Indian Ocean (Varnham et al. 2002). However, our maximum density of $73.7 /$ ha greatly exceeds known values and could indicate an irruptive potential for this species in the Mariana Islands.

Mus musculus was most common in grassland and mixed-habitat sites with patchy vegetation and exposed soil. Baker (1946:398) noted a similar preference for "open grass and brush land" and areas where "limestone soils are exposed" on Guam. Our M. musculus density estimates are comparable with historic values (8.3-25.8/ha [Baker 1946]) but less than more-recent estimates from Guam (18.5-104.0/ha [Gragg 2004]). Our estimates may have been influenced by $R$. diardii activity (Brown et al. 1996). To investigate this possibility, we added site-specific $R$. diardii density as both a linear and quadratic function to the top M. musculus model. There was limited support for the linear model $\left(\Delta \mathrm{AIC}_{\mathrm{c}}=0.21\right)$, indicating that $R$. diardii density had a weak negative effect on $M$. musculus capture probability $(\beta=-0.008 \pm$ 0.006 [logit scale], 95\% CI $=-0.019-0.003)$.

When interpreting our density and biomass estimates, it is critical to recognize the potential for site-specific temporal variability. Annual sampling over $3 \mathrm{yr}$ at a single site on Guam (Leucaena forest 4) revealed significant temporal variation in $R$. diardii density and biomass, which increased from 2.6/ha and $0.4 \mathrm{~kg} / \mathrm{ha}$, respectively, in 2005 to $15.3 / \mathrm{ha}$ and $2.9 \mathrm{~kg} / \mathrm{ha}$ in 2006. In 2007, 10 days of livetrapping (1,570 trap nights) yielded zero captures. Sampling occurred at the same time each year (early May-early June) and therefore represents annual variability, as opposed to intra-annual variability, which was not examined during this study.

\section{Modeling Capture and Recapture Probability}

By modeling the effects of temporal variation, spatial variation, and heterogeneity on capture and recapture probability, we were able to generate robust and reliable estimates of density and biomass. Knowledge of these effects may also prove beneficial for planning future sampling and data analysis.

TEMPORAL VARIATION. We documented lower capture probability for $R$. diardii on the first and second occasion, likely due to neophobia. Neophobia has been observed in laboratory, commensal, and wild Rattus populations (Temme and Jackson 1979, Inglis et al. 1996, Clapperton 2006). Suncus murinus capture probability also increased over time, suggesting neophobia, although this effect was not strongly supported in models. Although some researchers have documented a similar response (e.g., fig. 6 in Seymour et al. [2005]), the general consensus is that $S$. murinus is neophilic and likely to investigate, rather than avoid, new objects (Churchfield 1990). The pattern of temporal variation was less clear for M. musculus, although there was an indication of increasing capture probability over time on Rota, Saipan, and Tinian. Extended trap acclimation (greater than 2 nights) or prebaiting might reduce temporal variation in capture probability.

SPATIAL VARIaTion. For each species, we documented capture or recapture probability variation by island, potentially due to a combination of differing land-use histories and ungulate and predator densities. Each island has experienced substantial but variable disturbance as a result of military activities and loss of native habitats to agriculture and development. The vegetative community has also been modified by introduced ungulates, including feral pigs (Sus scrofa) and Philippine deer (Cervus mariannus) on Guam, Rota, and 
Saipan (Stinson 1994, Vogt and Williams 2004, Wiles 2005) and domestic cattle (Bos taurus) on Tinian (Wiles et al. 1990). In addition to the Brown Tree Snake on Guam, each island is home to a variety of potential predators, including feral cats (Felis catus) and dogs (Canis familiaris) and monitor lizards (Varanus indicus [Stinson 1994, Fritts and Rodda 1998, Vogt and Williams 2004, Wiles 2005]).

HETEROGENEITY. The addition of covariates improved the precision of site-specific $R$. diardii abundance estimates by an average of $25.7 \%$ (range: $8.1 \%-57.2 \%$ ). The importance of sex (female $>$ male) and reproductive status (reproductively active $>$ nonreproductive) suggests that social structure and dominance influenced capture and recapture probability. These results are consistent with those of Ewer (1971), who found that female $R$. rattus were more aggressive than males and adults were generally dominant over juveniles. We speculate that the positive relationship between rainfall and capture probability resulted from increased activity as individuals searched for standing water after rainfall events. The limestone substrate of the Mariana Islands is highly permeable, and available surface water is typically rare or nonexistent (Mueller-Dombois and Fosberg 1998). Thus, other than the moisture available in food items, surface water may be limited except immediately after rainfall. For $S$. murinus and $M$. musculus, heterogeneity in capture and recapture probability was accounted for with two-mixture models, rather than covariates. Other researchers have documented heterogeneity in capture probability for S. murinus (Seymour et al. 2005) and $M$. musculus (Conn et al. 2006).

\section{Implications for Ecology in the Mariana Islands}

Although the negative effects of introduced small mammals on island ecology are well documented (Atkinson 1985, Towns et al. 2006, Jones et al. 2008), little direct evidence exists for the Mariana Islands. However, it is likely that the high-density populations documented during our research have negative effects on native species in the Mariana Is- lands (Fritts and Rodda 1998). In recent years, researchers have noted apparent declines of several avian species, including the bridled white-eye (Zosterops conspicillatus rotensis [Fancy and Snetsinger 2001]) and Mariana crow (Corvus kubaryi [Plentovich et al. 2005, U.S. Fish and Wildlife Service 2005]) on Rota and the Micronesian megapode (Megapodius laperouse) and Mariana fruit dove (Ptilinopus roseicapilla) on Saipan (Craig 1999). The potential role of introduced small mammals in recent declines is often disregarded because $R$. exulans has been present in the Mariana Islands for at least 1,000 yr (Steadman 1999). However, R. exulans is generally considered less detrimental to birds than other introduced Rattus species (Atkinson 1985, Thibault et al. 2002, Towns et al. 2006, Jones et al. 2008). More important, the impact of $R$. diardii on birds in the Mariana Islands is unclear at this time. Further, temporal shifts in the abundance or distribution of Rattus species may obscure their role in avian declines. High-density introduced small mammal populations on Rota, Saipan, and Tinian might also impact avian species through dietary competition. Competition for invertebrate and reptilian prey could be especially problematic for nesting birds, because these highprotein items are required for nestlings.

Introduced Rattus species have also been implicated in invertebrate and reptilian declines (Whitaker 1973, Towns et al. 2006, Hoare et al. 2007), although the insectivorous S. murinus may be more problematic for these taxa in the Mariana Islands. This species has been implicated in the decline of invertebrates and reptiles on Mauritius and nearby islands (Varnham et al. 2002). On Guam, Barbehenn (1974b) observed no skinks during the peak of the $S$. murinus irruption in the early 1960s, which contrasts with the current abundance and visibility of skinks on Guam. More recently, Fritts and Rodda (1998) documented large differences in skink density between Saipan, where S. murinus was common $(2,200$ skinks/ha), and areas on Guam with few S. murinus (8,850 skinks/ha). Similarly, Rodda and Fritts (1992) implicated S. murinus in the decline of the pelagic gecko (Nactus 
pelagicus), which was common on Rota, where S. murinus was absent, but uncommon or possibly extinct on Guam, Saipan, and Tinian, where S. murinus was historically or currently abundant.

\section{Implications for Brown Tree Snake Control and Management}

Introduced small mammals have important impacts on the effectiveness of Brown Tree Snake control efforts, which are highly dependent on traps using live, domestic mice (M. musculus) as attractants. These traps are placed around airports, seaports, and other cargo-handling facilities on Guam, as well as in locations vulnerable to accidental brown tree snake introductions, such as Rota, Saipan, and Tinian. Mouse-attractant traps are also commonly deployed in response to snake sightings in Brown Tree Snake-free locations. However, recent research suggests that Brown Tree Snake trap capture rates are inversely related to small mammal density. For example, Rodda et al. (2001) found a strong correlation $\left(R^{2}=0.90\right)$ between Brown Tree Snake capture rates and indices of small mammal density and documented a sevenfold increase in Brown Tree Snake capture rates in areas of very low small mammal density on Guam. Similarly, Gragg et al. (2007) documented a $22 \%-65 \%$ increase in Brown Tree Snake capture probability after reducing small mammal density with localized rodenticide application. Our small mammal density estimates suggest reduced effectiveness of mouse-attractant traps on Rota, Saipan, and Tinian. Further, the majority of Brown Tree Snake control and eradication tools currently being developed, such as acetaminophen delivery devices (Savarie et al. 2001), also rely on mouse-based attractants and will likely be subject to the same reduced effectiveness in areas of high small mammal density.

A second, though perhaps less obvious, effect of introduced small mammals on Brown Tree Snake control and management relates to their impact on island trophic systems and predator-prey relationships. On Guam, introduced prey species, including small mammals, skinks, and geckos, were abundant and widespread at the time of Brown Tree Snake introduction (Baker 1946, Fritts and Rodda 1998). Because these species evolved with predators, they were better able to persist under Brown Tree Snake predation than the predatornaive species native to Guam. These introduced prey species facilitated and supported a high-density Brown Tree Snake population, even as native avian and reptilian species declined (Fritts and Rodda 1998), a phenomenon known as hyperpredation (Courchamp et al. 2000). By the time Brown Tree Snake predation pressure began to reduce introduced prey densities (forcing a decline in Brown Tree Snake density), many native species were already extinct. The high-density introduced small mammal populations documented on the islands of Rota, Saipan, and Tinian during our study suggest that a similar scenario could develop should a Brown Tree Snake population become established on those islands.

\section{ACKNOWLEDGMENTS}

We are indebted to numerous individuals who assisted with site preparation and data collection, including R. Bischof, V. Boyarski, I. Chellman, M. Christy, J. Farley, E. Fidler, G. George, A. Hambrick, T. Hinkle, P. Reynolds, S. Siers, J. Stanford, A. Tuggle, and J. Willey. Logistical support was provided by the Commonwealth of the Northern Mariana Islands Division of Fish and Wildlife (A. Castro, N. Hawley, L. Williams, and R. Ulloa), Guam Division of Aquatic and Wildlife Resources (P. Wenninger), U.S. Air Force (D. Lujan), U.S. Department of Agriculture/ Animal and Plant Health Inspection Service Wildlife Services (C. Clark), U.S. Navy (A. Brooke, S. Vogt, and R. Wescom), and U.S. Fish and Wildlife Service (C. Bandy, G. Deutscher, and C. Kessler). A. Ellingson assisted with study design, and S. Converse and T. R. Stanley provided helpful feedback during data analysis. S. Oyler-McCance coordinated analysis of Rattus genetic samples. We thank B. Lardner, W. Pitt, and K. Swift for comments on early drafts of the manuscript. 


\section{Literature Cited}

Anderson, D. R. 2001. The need to get the basics right in wildlife field studies. Wildl. Soc. Bull. 29:1294-1297.

- 2003. Response to Engeman: Index values rarely constitute reliable information. Wildl. Soc. Bull. 31:288-291.

Atkinson, I. A. E. 1985. The spread of commensal species of Rattus to oceanic islands and their effects on island avifaunas. Pages 35-81 in P. J. Moors, ed. Conservation of island birds. International Council for Bird Preservation, Technical Publication No. 3, Cambridge, England.

Baker, R. H. 1946. A study of rodent populations on Guam, Mariana Islands. Ecol. Monogr. 16:393-408.

Barbehenn, K. R. 1969. Responses of rodents and shrews to patterns of removal trapping. Pages 247-252 in D. W. Parrack, ed. Indian rodent symposium. Calcutta, India.

- 1974a. Estimating density and home range size with removal grids: The rodents and shrews of Guam. Acta Theriol. 19:191-234.

. 1974b. Recent invasions of Micronesia by small mammals. Micronesica 10:4150.

Bowden, D. C., G. C. White, A. B. Franklin, and J. L. Ganey. 2003. Estimating population size with correlated sampling unit estimates. J. Wildl. Manage. 67:1-10.

Brown, K. P., H. Moller, J. Innes, and N. Alterio. 1996. Calibration of tunnel tracking rates to estimate relative abundance of ship rats (Rattus rattus) and mice (Mus musculus) in a New Zealand forest. N. Z. J. Ecol. 20:271-275.

Burnham, K. P., and D. R. Anderson. 2002. Model selection and multimodel inference: A practical information-theoretic approach. 2nd ed. Springer, New York.

Campbell, D. J., and I. A. E. Atkinson. 2002. Depression of tree recruitment by the Pacific rat (Rattus exulans Peale) on New Zealand's northern offshore islands. Biol. Conserv. 107:19-35.

Chanteau, S., L. Ratsifasoamanana, B. Rasoa- manana, L. Rahalison, J. Randriambelosoa, J. Roux, and D. Rabeson. 1998. Plague, a reemerging disease in Madagascar. Emerging Infect. Dis. 4:101-104.

Churchfield, S. 1990. The natural history of shrews. Christopher Helm, London.

Clapperton, B. K. 2006. A review of the current knowledge of rodent behaviour in relation to control devices. Sci. Conserv. 263. New Zealand Department of Conservation, Wellington.

Colvin, B. A., M. W. Fall, L. A. Fitzgerald, and L. L. Loope. 2005. Review of Brown Treesnake problems and control programs: Report of observations and recommendations. Report to Department of Interior, Office of Insular Affairs, Honolulu, Hawai'i, http://www.invasivespeciesinfo.gov/ animals/controlplans.shtml (accessed 15 February 2008).

Conn, P. B., A. D. Arthur, L. L. Bailey, and G. R. Singleton. 2006. Estimating the abundance of mouse populations of known size: Promises and pitfalls of new methods. Ecol. Appl. 16:829-837.

Courchamp, F., M. Langlais, and G. Sugihara. 2000. Rabbits killing birds: Modelling the hyperpredation process. J Anim. Ecol. 69:154-164.

Craig, R. J. 1999. Conservation of endangered white-eyes (Zosteropidae) in the tropical Pacific. Bird Conservation Research, Inc. Contribution No. 1:1-8, http://www.birdconservationresearch.org/ pdf/pub_1_conserv_wh_eye.pdf (accessed 15 February 2008).

Ewer, R. F. 1971. The biology and behaviour of a free-living population of black rats (Rattus rattus). Anim. Behav. Monogr. 4:127-174.

Falanruw, M. V. C., T. G. Cole, and A. H. Ambacher. 1989. Vegetation survey of Rota, Tinian, and Saipan, Commonwealth of the Northern Mariana Islands. Resource Bulletin PSW-27. USDA Forest Service, Pacific Southwest Forest and Range Experiment Station, Berkeley, California.

Fancy, S. G., and T. J. Snetsinger. 2001. What caused the population decline of 
the bridled white-eye on Rota, Mariana Islands? Pages 274-280 in J. M. Scott, S. Conant, and C. van Riper III, eds. Evolution, ecology, conservation, and management of Hawaiian birds: A vanishing avifauna. Studies in Avian Biology No. 22, Cooper Ornithological Society.

Freycinet, L. C. d. 2003. An account of the Corvette L' Uranie's sojourn at the Mariana Islands, 1819; supplemented with the journal of Rose de Freycinet. Occasional Historic Papers No. 13, Commonwealth of the Northern Mariana Islands Division of Historic Preservation, Saipan.

Fritts, T. H., and G. H. Rodda. 1998. The role of introduced species in the degradation of island ecosystems: A case history of Guam. Annu. Rev. Ecol. Syst. 29:113140.

Fukami, T., D. A. Wardle, P. J. Bellingham, C. P. H. Mulder, D. R. Towns, G. W. Yeates, K. I. Bonner, M. S. Durrett, M. N. Grant-Hoffman, and W. M. Williamson. 2006. Above- and below-ground impacts of introduced predators in seabirddominated island ecosystems. Ecol. Lett. 9:1299-1307.

Gannon, W. L., R. S. Sikes, and the Animal Care and Use Committee of the American Society of Mammalogists. 2007. Guidelines of the American Society of Mammalogists for the use of wild mammals in research. J. Mammal. 88:809-823.

Gragg, J. E. 2004. Rodent reduction for enhanced control of brown treesnakes (Boiga irregularis). M.S. thesis, Colorado State University, Fort Collins.

Gragg, J. E., G. H. Rodda, J. A. Savidge, G. C. White, K. Dean-Bradley, and A. R. Ellingson. 2007. Response of brown treesnakes to reduction of their rodent prey. J. Wildl. Manage. 71:2311-2317.

Harper, G., and D. Veitch. 2006. Population ecology of Norway rats (Rattus norvegicus) and interference competition with Pacific rats ( $R$. exulans) on Raoul Island, New Zealand. Wildl. Res. 33:539-548.

Hoare, J. M., S. Pledger, N. J. Nelson, and C. H. Daugherty. 2007. Avoiding aliens: Behavioural plasticity in habitat use enables large, nocturnal geckos to survive
Pacific rat invasions. Biol. Conserv. 136: 510-519.

Huggins, R. M. 1989. On the statistical analysis of capture-recapture experiments. Biometrika 76:133-140.

1991. Some practical aspects of a conditional likelihood approach to capture experiments. Biometrics 47:725-732.

Inglis, I. R., D. S. Shepherd, P. Smith, P. J. Haynes, D. S. Bull, D. P. Cowan, and D. Whitehead. 1996. Foraging behaviour of wild rats (Rattus norvegicus) towards new foods and bait containers. Appl. Anim. Behav. Sci. 47:175-190.

Jackson, W. B. 1967. Productivity in high and low islands with special emphasis to rodent populations. Micronesica 3:5-15.

Jones, H. P., B. R. Tershy, E. S. Zavaleta, D. A. Croll, B. S. Keitt, M. E. Finkelstein, and G. R. Howald. 2008. Severity of the effects of invasive rats on seabirds: A global review. Conserv. Biol. 22:16-26.

Kuroda, N. 1938. A list of the Japanese mammals. Privately printed, Tokyo, Japan.

Moller, H., and J. L. Craig. 1987. The population ecology of Rattus exulans on Tiritiri Matangi Island, and a model of comparative population dynamics in New Zealand. N. Z. J. Zool. 14:305-328.

Mueller-Dombois, D., and F. R. Fosberg. 1998. Vegetation of the tropical Pacific islands. Springer, New York.

Musser, G. G., and M. D. Carleton. 2005. Family Muridae. Pages 1189-1531 in D. E. Wilson and D. M. Reeder, eds. Mammal species of the world: A taxonomic and geographic reference. 3rd ed. Smithsonian Institution Press, Washington, D.C.

Parker, I. M., D. Simberloff, W. M. Londsdale, K. Goodell, M. Wonham, P. M. Kareiva, M. H. Williamson, B. V. Holle, P. B. Moyle, J. E. Byers, and L. Goldwasser. 1999. Impact: Towards a framework for understanding the ecological effects of invaders. Biol. Invasions 1:3-19.

Peterson, G. D., Jr. 1956. Suncus murinus, a recent introduction to Guam. J. Mammal. 37:278-279.

Pickering, J., and C. A. Norris. 1996. New evidence concerning the extinction of the endemic murid Rattus macleari from 
Christmas Island, Indian Ocean. Aust. Mammal. 19:19-25.

Pledger, S. 2000. Unified maximum likelihood estimates for closed capture-recapture models using mixtures. Biometrics 56:434442.

Plentovich, S., J. M. Morton, J. Bart, R. J. Camp, M. R. Lusk, N. C. Johnson, and E. A. VanderWerf. 2005. Population trends of Mariana crow (Corvus kubaryi) on Rota, Commonwealth of the Northern Mariana Islands. Bird Conserv. Int. 15:211-224.

Robins, J. H., M. Hingston, E. MatisooSmith, and H. A. Ross. 2007. Identifying Rattus species using mitochondrial DNA. Mol. Ecol. Notes 7:717-729.

Rodda, G. H., K. Dean-Bradley, and C. P. Qualls. 2001. The effect of prey density on brown treesnake capture probability. Brown Treesnake 2001: Research \& management. Micronesica 37:181-182.

Rodda, G. H., and T. H. Fritts. 1992. The impact of the introduction of the brown tree snake, Boiga irregularis, on Guam's lizards. J. Herpetol. 26:166-174.

Savarie, P. J., J. A. Shivik, G. C. White, J. C. Hurley, and L. Clark. 2001. Use of acetaminophen for large-scale control of brown treesnakes. J. Wildl. Manage. 65:356-365.

Savidge, J. A. 1986. The role of disease and predation in the decline of Guam's avifauna. Ph.D. diss., University of Illinois, Urbana-Champaign.

1987. Extinction of an island forest avifauna by an introduced snake. Ecology 68:660-668.

1991. Population characteristics of the introduced brown tree snake (Boiga irregularis) on Guam. Biotropica 23:294300.

Seber, G. A. F. 2002. The estimation of animal abundance and related parameters. 2nd ed. The Blackburn Press, New Jersey.

Seymour, A., K. Varnham, S. Roy, S. Harris, L. Bhageerutty, S. Church, A. Harris, N. V. Jennings, C. O. Jones, A. Khadun, J. Mauremootoo, T. Newman, V. Tatayah, C. Webbon, and G. Wilson. 2005. Mechanisms underlying the failure of an attempt to eradicate the invasive Asian musk shrew Suncus murinus from an island nature reserve. Biol. Conserv. 125:23-35.

Steadman, D. W. 1999. The prehistory of vertebrates, especially birds, on Tinian, Aguiguan, and Rota, Northern Mariana Islands. Micronesica 31:319-345.

Stickel, L. F. 1946. The source of animals moving into a depopulated area. J. Mammal. 27:301-307.

Stinson, D. W. 1994. Birds and mammals recorded from the Mariana Islands. Nat. Hist. Res. Spec. Issue 1:333-344.

Strecker, R. L. 1962. Population levels. Pages 74-79 in T. I. Storer, ed. Pacific island rat ecology: Report of a study made on Ponape and adjacent islands 1955-1958. Bernice P. Bishop Mus. Bull. 225.

Temme, M., and W. B. Jackson. 1979. Criteria for trap evaluation. ASTM Spec. Tech. Publ. 680:58-67.

Thibault, J.-C., J.-L. Martin, A. Penloup, and J.-Y. Meyer. 2002. Understanding the decline and extinction of monarchs (Aves) in Polynesian islands. Biol. Conserv. 108:161-174.

Towns, D. R. 1999. Interactions between geckos, honeydew scale insects and host plants revealed on islands in northern New Zealand, following eradication of introduced rats and rabbits. Pages 329-335 in C. R. Veitch and M. N. Clout, eds. Turning the tide: The eradication of invasive species. IUCN SSC Invasive Species Specialist Group. IUCN, Gland, Switzerland, and Cambridge, United Kingdom.

Towns, D., I. Atkinson, and C. Daugherty. 2006. Have the harmful effects of introduced rats on islands been exaggerated? Biol. Invasions 8:863-891.

U.S. Fish and Wildlife Service. 2005. Draft revised recovery plan for the aga or Mariana crow (Corvus kubaryi). Portland, Oregon.

Varnham, K., S. S. Roy, A. Seymour, J. Mauremootoo, C. G. Jones, and S. Harris. 2002. Eradicating Indian musk shrews (Suncus murinus, Soricidae) from Mauritian offshore islands. Pages 342-349 in C. R. Veitch and M. N. Clout, eds. Turning the tide: The eradication of invasive species. 
IUCN SSC Invasive Species Specialist Group. IUCN, Gland, Switzerland, and Cambridge, United Kingdom.

Vogt, S. R., and L. L. Williams. 2004. Common flora and fauna of the Mariana Islands. Privately printed, Saipan, Northern Mariana Islands.

Whitaker, A. H. 1973. Lizard populations on islands with and without Polynesian Rats, Rattus exulans (Peale). Proc. N. Z. Ecol. Soc. 20:121-130.

White, G. C., and K. P. Burnham. 1999. Program MARK: Survival estimation from populations of marked animals. Bird Study 46 (Supplement): 120-138.
Wiles, G. J. 2005. A checklist of the birds and mammals of Micronesia. Micronesica 38:141-189.

Wiles, G. J., A. B. Amerson Jr., and R. E. Beck Jr. 1990. The mammals of Tinian, Mariana Islands. Micronesica 23:167180.

Wilson, K. R., and D. R. Anderson. 1985. Evaluation of two density estimators of small mammal population size. J. Mammal. 66:13-21.

Wirtz, W. O., II. 1972. Population ecology of the Polynesian rat, Rattus exulans, on Kure Atoll, Hawaii. Pac. Sci. 26:433464. 